\title{
Agro-industrial byproducts in rabbit food: Case of the complex of detoxified apricot kernel cake and dehydrated tomato pulp
}

\author{
Yasmine Arbouche ${ }^{1}$, Achour Mennani ${ }^{1}$, Lamya Ouzzir ${ }^{1}$, Rafik Arbouche ${ }^{2}$ and Fodil Arbouche ${ }^{2}$ (D) \\ 1. Department of Agronomy, Faculty of Science of Nature and Life, University of Setif1, Algeria; 2. Department of \\ Agronomy, Faculty of Science of Nature and Life, University of Ghardaia, Algeria. \\ Corresponding author: Fodil Arbouche, e-mail: arbouchefodil@yahoo.fr \\ Co-authors: YA: yas.arbouche@yahoo.fr, AM: achour_mennani@yahoo.fr, LO: lamou.oua@gmail.com, \\ RA: rafik_arbouche@yahoo.fr \\ Received: 23-10-2020, Accepted: 01-02-2021, Published online: 23-03-2021
}

doi: www.doi.org/10.14202/vetworld.2021.744-750 How to cite this article: Arbouche Y, Mennani A, Ouzzir L, Arbouche R, Arbouche F (2021) Agro-industrial byproducts in rabbit food: Case of the complex of detoxified apricot kernel cake and dehydrated tomato pulp, Veterinary World, 14(3): 744-750.

\begin{abstract}
Background and Aim: The use of agro-industrial byproducts as an unconventional source of raw materials for monogastric feed is one possible solution. This study aimed to determine the effects of incorporating detoxified apricot kernel meal (DAKM) as a substitute for soybean meal and dehydrated tomato pulp (DTP) as a substitute for alfalfa hay on the local rabbit fattening.
\end{abstract}

Materials and Methods: A total of 120 white strain rabbits, weaned at 33 days, were randomly assigned to four groups of 30. The rabbits in each group were ringed, placed in cages at 6 rabbits/cage, and fed according to DAKM and DTP incorporation rates $(0 \%, 30 \%, 40 \%$, and $60 \%)$.

Results: The weights at 77 days were improved $(p<0.05)$ with unchanged mean daily intakes. The vast majority of slaughter parameters and carcass characteristics improved. The chemical composition of the meat constituents improved significantly, with a $60 \%$ increase in the protein content of the batch $(26.55 \%$ vs. $28.53 \%), 38 \%$ reduction in the total feed cost, and 40 DA saved for each kilogram of feed consumed per rabbit. The relative economic efficiency improved in proportion to the substitution rates of soybean meal by DAKM and alfalfa hay by DTP.

Conclusion: Substituting DAKM and DTP, as byproducts of agro-industrial processing, for up to $60 \%$ induced satisfactory results in rabbit fattening. Therefore, it would be more insightful to increase the incorporation rates to determine the optimal threshold.

Keywords: agro-industrial byproducts, apricot kernel cake, rabbit fattening, tomato pulp, zootechnical performances.

\section{Introduction}

Algeria is one of the top producers of rabbit meat in Africa. The intensive production of rabbits (Oryctolagus cuniculus) has several advantages that solve a part of the worldwide shortage in animal protein $[1,2]$. Rabbit diet accounts for up to $70 \%$ of production costs [3], which are mainly due to the importation of most raw materials used in feed formulas. The short-term solution lies in the introduction of agricultural and agro-industrial byproducts into feed formulas [4-8], which would make it possible, in the short term, to make meat products available to the poorest populations at a lower cost. In rabbit farming, agro-industrial byproducts, such as apricot kernel cake and date scraps, have been successfully introduced at a rate of $30 \%[9,10]$ and apricot kernel cake alone at a rate of $60 \%$ [11]. In the framework of the continuity of this approach, this study aimed

Copyright: Arbouche, et al. Open Access. This article is distributed under the terms of the Creative Commons Attribution 4.0 International License (http://creativecommons.org/licenses/ by/4.0/), which permits unrestricted use, distribution, and reproduction in any medium, provided you give appropriate credit to the original author(s) and the source, provide a link to the Creative Commons license, and indicate if changes were made. The Creative Commons Public Domain Dedication waiver (http:// creativecommons.org/publicdomain/zero/1.0/) applies to the data made available in this article, unless otherwise stated. to introduce the byproducts, such as the apricot kernel cake versus soybean cake and tomato pulp versus dehydrated alfalfa, in rabbit feed.

The tomato pulp generated by processing the latter is important in the northeast region of the country. This weeded crop is grown on an area of 21,434 ha for an estimated production of 1.235 million tons per year, $85 \%$ of which is concentrated in the Wilayas of Skikda, Annaba, Guelma, and El-Tarf [12]. With 27 processing units, about $13 \%$ of these are byproducts [13], or 160,602 T/year, consisting mainly of seeds, husks, and stalks.

The tomato pulp in rabbit feed can be effectively used for up to $20 \%$ incorporation rate, as it was tested extensively by some authors $[14,15]$. However, this rate varies as the chemical composition and nutritional value of this byproduct depend on the environment, the soil in particular, and the level of fertilization. The tomato pulp from national processing units is relatively rich in cellulosic fiber, protein, and fat $(35.3 \%$, $19.90 \%$, and $16.1 \%$, respectively) [15].

In Algeria, the stone fruit arboriculture is dominated by apricot trees, with about 46,000 hectares for an average annual production of $293,486 \mathrm{~T}$, which is mainly concentrated (40\%) in the region of Hodna, inducing the establishment of several processing units [12]. These 
units produce large quantities of byproducts each year, which are mostly cores. For El-Adawy et al. [16], the apricot kernel represents $15-16 \%$ of the apricot, while the almond represents $30-38 \%$ of the kernel. According to Ferradji et al. [17], the oil yield after crushing and pressing the apricot kernel is estimated to be $33 \%$ for $67 \%$ of the cake. Based on these data, the quantity of apricot kernel cake is estimated to be 106,970 T/year.

There are only a few studies on the use of apricot kernel cake as a protein source in animal feed, and its incorporation has been tested in broiler chicken [4], sheep in fertilizer [5], and in association with other byproducts in rabbit farming $[9,10]$. This coproduct contains a significant protein content (42.3\%) [15].

\section{Materials and Methods}

\section{Ethical approval}

The present study was conducted after approval of the Institutional Animal Ethics Committee laboratory of the Agriculture department of Ghardaia University, Algeria.

\section{Study period and location}

To guarantee the maintenance of environmental conditions, the test was carried out in a $200-\mathrm{m}^{2}$ building with a pad cooling system and fans in a professional rabbit breeding center (Wilaya of Sétif, Algeria), during the month of April 2019.

\section{Animals, food, and experimental protocol}

One hundred and twenty white strain bunnies, weaned at 33 days, were randomly divided into four groups of 30 . The rabbits in each group were ringed and placed in cages at a rate of six rabbits per cage, that is, five repetitive batches per group. The sex of the rabbits was not given particular attention because until 15 [18] and 20 weeks of age [19], the males and females followed a similar growth curve and body composition.

The apricot kernel cake was supplied by an oil extraction unit located in Beni Ourtilane, Wilaya of Sétif. It was detoxified according to the method of Gabrial et al. [20]. The tomato pulp was supplied by the Nouvelle Ere canning factory in the industrial zone of the Wilaya of Sétif. It was dried in the sun for 3 days. The chemical compositions of detoxified apricot kernel meal (DAKM) and dehydrated tomato pulp (DTP) are shown in Table-1 [21,22].

Four compound feeds were formulated using WUFFDA [23]; one control and three experimental feeds, in which we substituted 30,40 , and $60 \%$ of the soybean meal with DAKM and alfalfa hay with DTP (Table-2).

The animals were individually weighed at 33 , 44,58 , and 77 days of age, and the feed was distributed at will; The consumption of each cage was checked every week of the experiment at a specific time. The average daily gains (ADG g/day), average daily intakes (ADI g/day), and conversion indices (CI) were calculated. The water was available ad libitum through the automatic pipette-type drinkers.
Table-1: Chemical composition of detoxified almond cake (DAKM) and DTP in \% DM.

\begin{tabular}{lcc}
\hline Parameter & DAKM & DTP \\
\hline Organic matter & 96.7 & 95.12 \\
Total nitrogenous matter & 42.3 & 16.11 \\
Crude fiber & 7.7 & 37.92 \\
Fat & 10.4 & 10.22 \\
Mineral content & 3.3 & 4.88 \\
Nitrogen-free extract & 36.3 & 30.87 \\
HCN (mg/100 g DM) & 102 & $/$ \\
NDF & 18.4 & 52.69 \\
ADF & 10.7 & 42.32 \\
ADL & 7.4 & 20.33 \\
Hémicellulose & 7.7 & 10.37 \\
Gross energy (kcal/kg DM) & 5180 & 4063 \\
Digestible rabbit energy (kcal/kg DM)* & 3984 & 2298 \\
Digestible rabbit protein (g/kg of DM)* & 336 & 130.6 \\
Lysine (g/100 g of foodstuff) & 1.8 & 1.0 \\
Méthionine (g/100 g of foodstuff) & 1.2 & 0.36 \\
Cystine (g/100 g of foodstuff) & 1.3 & 0.31 \\
\hline
\end{tabular}

$\mathrm{DM}=$ Dry matter, NDF $=$ Neutral detergent fiber,

$A D F=$ Acid detergent fiber, $A D L=$ Acid detergent lignin, DAKM=Detoxified apricot kernel meal, DTP=Dehydrated tomato pulp. *Estimated by the equation $[21,22]$

Table-2: Formula (kg/100 kg of feed) of feed distributed based on the substitution rate of soybean meal by DAKM and alfalfa by DTP.

\begin{tabular}{lcccc}
\hline Percentage of substitution & $\mathbf{0 \%}$ & $\mathbf{3 0 \%}$ & $\mathbf{4 0 \%}$ & $\mathbf{6 0 \%}$ \\
\hline Corn & 20 & 20 & 20 & 20 \\
Soybean meal & 12.7 & 8.9 & 7.6 & 5.1 \\
Apricot kernel meal & 0 & 3.8 & 5.1 & 7.6 \\
Wheat bran & 32 & 32 & 32 & 32 \\
Wheat straw & 4.7 & 4.7 & 4.7 & 4.7 \\
Dried alfalfa & 29 & 20.3 & 17.4 & 11.6 \\
Tomato pulp & 0 & 8.7 & 11.6 & 17.4 \\
Salt (NaCl) & 0.5 & 0.5 & 0.5 & 0.5 \\
Rabbit premix (CMV) & 0.5 & 0.5 & 0.5 & 0.5 \\
Calcium carbonate & 0.5 & 0.5 & 0.5 & 0.5 \\
L-Lysine & 0.08 & 0.08 & 0.08 & 0.08 \\
DL-Methionine & 0.02 & 0.02 & 0.02 & 0.02 \\
Content of calculated nutrients & & & & \\
Crude fiber (\%) & 15.7 & 15.1 & 15.8 & 16.4 \\
NDF (\%) & 36.6 & 37.1 & 37.2 & 37.5 \\
ADF (\%) & 20.1 & 20.5 & 20.6 & 20.9 \\
ADL (\%) & 4.3 & 5.4 & 5.8 & 6.5 \\
Hemicellulose (\%) & 16.6 & 16.6 & 16.6 & 16.6 \\
Lysine (\%) & 0.83 & 0.82 & 0.85 & 0.88 \\
Methionine (\%) & 0.29 & 0.27 & 0.26 & 0.24 \\
Total sulfur amino acids (\%) & 0.50 & 0.51 & 0.53 & 0.55 \\
Digestible proteins (\%) & 10.6 & 10.7 & 10.8 & 10.9 \\
Digestible rabbit energy (kcal/kg) & 2335 & 2374 & 2387 & 2412 \\
Metabolizable rabbit energy & 2187 & 2213 & 2222 & 2239 \\
(kcal/kg) & & & & \\
Cellulose VS ADF-ADL\% & 15.7 & 15.1 & 14.8 & 14.4 \\
PD/ED calculated g/1000 kcal & 48.4 & 48.6 & 48.6 & 48.7 \\
\hline DAM Detoxifed a ricot kernel & & & &
\end{tabular}

DAKM=Detoxified apricot kernel meal, DTP=Dehydrated tomato pulp, $\mathrm{CMV}=$ Cytomegalovirus, $\mathrm{NDF}=$ Neutral detergent fiber, $A D F=$ Acid detergent fiber, $A D L=A c i d$ detergent lignin

The slaughter parameters, carcass characteristics, and meat chemical composition were determined on the ten rabbits in each group according to the methods proposed by Dalle Zotte et al. [24]. 


\section{Slaughter parameters}

Live weight at slaughter (LWS) (g); hot carcass weight $(\mathrm{HCW})(\mathrm{g})$; cold carcass weight $(\mathrm{CCW})(\mathrm{g})$; reference carcass weight $(\mathrm{g})$; hot carcass yield $(\mathrm{HCW} /$ LWS $\times 100)$; cold carcass yield $(\mathrm{CCW} / \mathrm{LWS} \times 100)$; and muscle/bone ratio.

\section{Carcass characteristics}

Liver weight (LW) (g); LW/live weight ratio at slaughter $(\mathrm{LW} / \mathrm{LWS} \times 100)$; peri-renal fat weight (PRFW) (g); peri-renal fat/live weight ratio (PRFW/ LWS $\times 100)$; peri-renal fat/hot carcass ratio $(\mathrm{PRFW} /$ $\mathrm{HCW} \times 100)$; skin weight $(\mathrm{SW})(\mathrm{g})$; SW/live weight ratio $(\mathrm{SW} / \mathrm{LWS} \times 100)$; weight of digestive tract full $(\mathrm{WDTF})(\mathrm{g}) ; \mathrm{WDTF} / \mathrm{LWS} \times 100$ ratio; front part weight $(\mathrm{FPW})(\mathrm{g})$; rear part weight $(\mathrm{RPW})(\mathrm{g})$; intermediate part weight "rable" (IPW) (g); FPW/HCW ratio (\%); $\mathrm{RPW} / \mathrm{HCW}$ ratio (\%); and the ratio IPW/HCW (\%).

\section{Meat quality}

In the longissimus lumborum muscle, the $\mathrm{pH}$ was measured directly $24 \mathrm{~h}$ postmortem using a $\mathrm{pH}$ meter, and the chemical composition of meat was determined according to the AOAC method [21] with three replicates. The analyses included the water content, protein content, fat content, and mineral content. After $24 \mathrm{~h}$ in the cold room $\left(6^{\circ} \mathrm{C}\right)$, the weight of the cold carcass was determined.

\section{Statistical analysis}

The data were prepared using the Microsoft Excel sheet. Statistical analysis and comparison of the means between the different diets (control and experimental) were performed by unidirectional analysis of variance using the SPSS software version 21 (IBM Corp., NY, USA). Student-Newman-Keuls and Duncan's test were done if a significant difference at $5 \%$ standard error was found $(\mathrm{p}<0.05)$.

\section{Economic efficiency}

The economic efficiency was calculated from the equation of Asar et al. [25]:

Economic efficiency $(\%)=[$ Net income/Total feed cost $] \times 100$.

Where:

Net income $=$ Price of weight gain - Total feed cost.

Weight gain price $=$ Average weight gain $(\mathrm{kg} / \mathrm{sub}$ ject) $\times$ price of $1 \mathrm{~kg}$ body weight.

Total feed cost $=$ Average consumption $(\mathrm{kg} / \mathrm{sub}$ ject) $\times$ price of $1 \mathrm{~kg}$ of feed.

The cost of each $\mathrm{kg}$ of feed for the control and experimental diets was calculated based on the local market price of ingredients at the time of the experiment (the year 2018). Ancillary costs were not included.

- For the experimental batch, the total feed cost also included the cost of purchasing and detoxifying the apricot kernel cake and the cost of purchasing and dehydrating the tomato pulp (Table-3).

The cost of the production of DAKM and DTP was calculated using the direct cost method, which
Table- 3: Data used to estimate the cost of DAKMs and DTPs.

\begin{tabular}{lcc}
\hline Parameter & $\begin{array}{c}\text { DAKM } \\
\text { Value } \\
\text { (DZD/T) }\end{array}$ & $\begin{array}{c}\text { DTP } \\
\text { Value } \\
\text { (DZD/T) }\end{array}$ \\
\hline Purchase & 300 & 5 \\
Transport cost & 100 & 100 \\
Truck unloading & 35 & 35 \\
$\begin{array}{l}\text { Treatment } \\
\text { The purchase of sodium }\end{array}$ & 80 & 0 \\
bicarbonate & 1 & 0 \\
Cost of water for rinsing & $1 \mathrm{~h} / \mathrm{T}$ & $/$ \\
The time required for treatment & $172 \mathrm{DZD} / \mathrm{h}$ & $/$ \\
Cost per hour of work for & 9 & 10 \\
treatment & $5 \mathrm{t} / \mathrm{h}$ & $2 \mathrm{t} / \mathrm{h}$ \\
Energy cost (drying) & 175 & 10 \\
Drying time & 200 & 100 \\
Total labor cost & 900 & 260 \\
$\quad$ Depreciation cost of equipment & Total &
\end{tabular}

DAKM $=$ Detoxified apricot kernel meal, DTP=Dehydrated tomato pulp

consists of allocating the direct fixed costs specific to the production of apricot kernel cake. The common costs were not negligible, but they were reported on all the company's products since they were difficult to evaluate in this study, which deals with only one byproduct.

- The basic wage in Algeria (SMIG) was 18,000 DZD/month if 35,000 DZD (gross wage+employer's contributions) was assumed, since the average wage per month was about $200 \mathrm{DZD} / \mathrm{h}$.

- The cost of energy was calculated by estimating the energy consumption of the material used for the production of oil cakes, knowing in the professional context, each $\mathrm{kWh}$ was charged at 4.472 $\mathrm{DZD} / \mathrm{kWh}[26]$.

- To rinse one ton of oilcake with water, about $10 \mathrm{~m}^{3}$ of water was needed, at a price of $1 \mathrm{DZD} / \mathrm{m}^{3}$, according to the Algerian Water Agency [27].

- The depreciation of the equipment was estimated according to its purchase price (Dryer, Industrial Tank, etc.) on the market and according to the average capacity of the companies carrying out the oil extraction.

\section{Results}

The substitution of soybean meal by DAKM and alfalfa hay by DTP had little effect on animal health status. Over the entire experimental period for all groups, a mortality rate of $<6 \%$ was recorded.

\section{Zootechnical performances}

The substitution of soybean meal with DAKM and dehydrated alfalfa with DTP improved the rabbit weights at 77 days for the experimental lots (Table-4). The weights at 44 days were higher for $40 \%$ and $60 \%$ groups. On day 58, the $30 \%$ group achieved better weight performance compared to the other groups (+65 points).

The ADG (33-44 days) for the $40 \%$ and $60 \%$ groups was optimal and similar, with an increase of 
+8 points over the control group, with the $30 \%$ group having a minimum of -14 points over the experimental group, and -6 points over the control group. However, for the ADG (45-58 days), the 30\% lot had a significantly higher value, with a difference of +16 points compared to the $40 \%$ and $60 \%$ lots, and -10 points compared to the control lot. For the experimental groups, the ADG (59-77 days) was significantly higher for the $40 \%$ and $60 \%$ lots, with the $30 \%$ lot having a lower value with -4 points. The control lot was the one with a lower value. Throughout the entire rearing period, the ADG (33-77 days) was significantly lower for the control lot ( -2 points) compared to experimental lots with similar values.

The ADI and CI were similar ( $p>0.05)$ for all groups during the entire rearing period (33-77 days) (Table-5). The CI (33-44 days) for the 0\% group was optimal (3.08) and remained similar for the other groups, with +0.23 points compared to the control group. The CI performance remained the same for all groups in the 44-58 days period. The CI (59-77 days) was depreciated and remained similar for the $0 \%$ and $30 \%$ groups, with a difference of +0.44 points compared with the $40 \%$ and $60 \%$ groups, which had similar values.

Table-4: Evolution of weight growth $(\mathrm{g})$ and ADG ( $\mathrm{g} / \mathrm{d}$ ) during fattening of bunnies as a function of the percentage of incorporation of the DAKM and DTP complex.

\begin{tabular}{lcccccc}
\hline & $\mathbf{0 \%}$ & $\mathbf{3 0 \%}$ & $\mathbf{4 0 \%}$ & $\mathbf{6 0 \%}$ & SEM & p-value \\
\hline Weight $_{(33 \mathrm{~d})}$ & 808 & 811 & 810 & 814 & 8.66 & 0.7 \\
Weight $_{(44 \mathrm{~d})}$ & $1088^{\mathrm{b}}$ & $1026^{\mathrm{c}}$ & $1177^{\mathrm{a}}$ & $1168^{\mathrm{a}}$ & 11.51 & 0.01 \\
Weight $_{(58 \mathrm{~d})}$ & $1456^{\mathrm{b}}$ & $1523^{\mathrm{a}}$ & $1465^{\mathrm{b}}$ & $1455^{\mathrm{b}}$ & 13.25 & 0.03 \\
Weight $_{(77 \mathrm{~d})}$ & $1992^{\mathrm{b}}$ & $2095^{\mathrm{a}}$ & $2099^{\mathrm{a}}$ & $2073^{\mathrm{a}}$ & 16.86 & 0.01 \\
ADG $_{(33-44 \mathrm{~d})}$ & $25.45^{\mathrm{b}}$ & $19.54^{\mathrm{c}}$ & $33.36^{\mathrm{a}}$ & $32.18^{\mathrm{a}}$ & 0.99 & 0.04 \\
ADG $_{(45-58 \mathrm{~d})}$ & $28.30^{\mathrm{b}}$ & $38.23^{\mathrm{a}}$ & $22.15^{\mathrm{c}}$ & $22.08^{\mathrm{c}}$ & 0.88 & 0.03 \\
ADG $_{(59-77 \mathrm{~d})}$ & $29.77^{\mathrm{c}}$ & $31.77^{\mathrm{b}}$ & $35.22^{\mathrm{a}}$ & $34.33^{\mathrm{a}}$ & 1.84 & 0.01 \\
ADG $_{(33-77 d)}$ & $28.19^{\mathrm{b}}$ & $30.57^{\mathrm{a}}$ & $30.69^{\mathrm{a}}$ & $29.98^{\mathrm{a}}$ & 0.94 & 0.03 \\
\hline
\end{tabular}

$\mathrm{ADG}=$ Average daily gain (the indices indicate the period in days over which this parameter was calculated). The presence of different letters on the same line indicates a significant difference between diets $(p<0.05)$. DAKM $=$ Detoxified apricot kernel meal, DTP $=$ Dehydrated tomato pulp

Table-5: Evolution of the $\mathrm{CI}(\mathrm{g} / \mathrm{g})$ and ADI ( $\mathrm{g} /$ days) during fattening of the young rabbits according to the percentage of incorporation of the DAKM and DTP complex.

\begin{tabular}{lcccccc}
\hline Parameter & $\mathbf{0 \%}$ & $\mathbf{3 0 \%}$ & $\mathbf{4 0 \%}$ & $\mathbf{6 0 \%}$ & ESM p-value \\
\hline $\mathrm{CI}_{(33-44 \mathrm{~d})}$ & $3.08^{\mathrm{b}}$ & $3.25^{\mathrm{a}}$ & $3.36^{\mathrm{a}}$ & $3.32^{\mathrm{a}}$ & 0.65 & 0.01 \\
$\mathrm{CI}_{(45-58 \mathrm{~d})}$ & 3.91 & 3.89 & 3.87 & 3.89 & 0.15 & 0.1 \\
$\mathrm{CI}_{(59-77 \mathrm{~d})}$ & $4.22^{\mathrm{a}}$ & $4.41^{\mathrm{a}}$ & $3.92^{\mathrm{b}}$ & $3.83^{\mathrm{b}}$ & 0.47 & 0.03 \\
$\mathrm{CI}_{(33-77 \mathrm{~d})}$ & 3.62 & 3.79 & 3.64 & 3.62 & 0.21 & 0.07 \\
$\mathrm{ADI}_{(33-44 \mathrm{~d})}$ & $72.20^{\mathrm{b}}$ & $77.24^{\mathrm{a}}$ & $74.40^{\mathrm{b}}$ & $73.51^{\mathrm{ab}}$ & 1.31 & 0.02 \\
$\mathrm{ADI}_{(45-58 \mathrm{~d})}$ & $93.60^{\mathrm{b}}$ & $100^{\mathrm{a}}$ & $95.63^{\mathrm{b}}$ & $92.97^{\mathrm{b}}$ & 2.01 & 0.04 \\
$\mathrm{ADI}_{(59-77 \mathrm{~d})}$ & $117.20^{\mathrm{a}}$ & $117.48^{\mathrm{a}}$ & $114.74^{\mathrm{b}}$ & $112.81^{\mathrm{c}}$ & 1.15 & 0.02 \\
$\mathrm{ADI}_{(33-77 \mathrm{~d})}$ & 96.00 & 98.26 & 94.92 & 93.10 & 4.1 & 0.14 \\
\hline
\end{tabular}

On the same line, the averages with distinct letters are significantly different at the $5 \%$ threshold. $\mathrm{CI}=$ Consumption indexes, $\mathrm{ADI}=$ Average daily intakes, $A D G=$ Average daily gain, $D A K M=$ Detoxified apricot kernel meal, DTP=Dehydrated tomato pulp
The ADI (33-44 days) and ADI (45-58 days) were the highest $(\mathrm{p}>0.05)$ for the $30 \%$ group compared with the other groups. The ADI (59-77 days) for the $60 \%$ group was lower compared with the other groups, which had similar values.

\section{Slaughter parameters, carcass characteristics, and chemical composition of the meat}

The incorporation of DAKM and DTP complex (up to 60\%) as a substitute for soybean meal and alfalfa hay, respectively, significantly improved the slaughter parameters $(\mathrm{p}<0.05)($ Table-6). The HCW and yields (HCW/LWS) from the $40 \%$ and $60 \%$ groups were similar and dominant over the $0 \%$ and $30 \%$ groups. The CCW of the experimental lots was higher $(p<0.05)$ than that of the control group, and so was the yield (CCW/LWS), which was superior for the $40 \%$ and $60 \%$ groups; the muscle/bone ratio remained dominant for these groups.

The liver and PRFW of the experimental groups were higher than those of the control group $(p>0.05)$, and so were the liver/Pva, Pgpr/Pva, and Pgpr/Pcc ratios. The SWs (pp) of the $40 \%$ and $60 \%$ lots were significantly higher (+14 points) than the $30 \%$ lot, which was +8 points higher than the control lot. The solid GI tract weights of all lots were similar $(p<0.05)$. The weights of the front part of the control and 30\% groups remained the same and lower than those of the $40 \%$ and $60 \%$ lots by about 50 points. The weight of the middle part remained unchanged for all groups. While similar, the weight of the rear part of the experimental groups was significantly higher than that of the control group.

The meat chemistry parameters of the experimental lots were significantly improved by substituting DAKM for soybean meal and DTP for alfalfa.

\section{Economic efficiency}

The substitution of soybean meal with DAKM and alfalfa hay with DTP in the diet of growing rabbits had a positive effect on economic efficiency (Table-7). Indeed, the $60 \%$ group achieved optimal economic efficiency of $25.82 \%$ compared to the control group, and a $25.95 \%$ reduction in the total feed cost, saving 9.1 DZD for each $\mathrm{kg}$ of feed produced. As a result, the net income per $\mathrm{kg}$ of meat produced changes proportionally to the substitution rates of soybean meal with DAKM and alfalfa hay with DTP.

\section{Discussion}

The overall mortality rate was low $(<6 \%)$. It was due to the transfer after weaning and the adaptation of the subjects to their new rearing conditions, as stated by De Blas [28]; however, it was still within the norms and range of what was recorded in national rabbit farms [29].

From the substitution of soybean meal with DAKM and alfalfa hay with DTP, the improvement of the overall performance of the experimental batches was mainly due to the increased efficiency in the use 
Table-6: Evolution of slaughter parameters and carcass characteristics of young rabbits at fattening according to the percentage of incorporation of the complex apricot kernel cake and tomato pulp.

\begin{tabular}{|c|c|c|c|c|c|c|}
\hline Slaughter parameters & $0 \%$ & $30 \%$ & $40 \%$ & $60 \%$ & ESM & p-value \\
\hline LWS (g) & 2138 & 2148 & 2128 & 2132 & 21.52 & 0.23 \\
\hline $\mathrm{HCW}(\mathrm{g})$ & $1320^{\mathrm{b}}$ & $1368^{b}$ & $1425^{\mathrm{a}}$ & $1463^{a}$ & 7.09 & 0.01 \\
\hline $\mathrm{CCW}(\mathrm{g})$ & $1273^{b}$ & $1340^{\mathrm{a}}$ & $1387^{a}$ & $1425^{a}$ & 25.35 & 0.03 \\
\hline Yield HCW/LWS (\%) & $61.73^{b}$ & $63.71^{b}$ & $66.93^{a}$ & $68.62^{\mathrm{a}}$ & 0.97 & 0.04 \\
\hline Yield CCW/LWS (\%) & $59.54^{c}$ & $62.40^{\mathrm{b}}$ & $65.13^{a}$ & $66.85^{\mathrm{a}}$ & 0.89 & 0.02 \\
\hline Yield muscle/bone & $7.24^{\mathrm{b}}$ & $7.86^{\mathrm{b}}$ & $8.41^{\mathrm{a}}$ & $8.03^{\mathrm{a}}$ & 0.86 & 0.03 \\
\hline \multicolumn{7}{|l|}{ Carcass characteristics } \\
\hline LW (g) & $70^{\mathrm{b}}$ & $74.3^{\mathrm{a}}$ & $75^{\mathrm{a}}$ & $75.6^{\mathrm{a}}$ & 1.09 & 0.04 \\
\hline Ratio LW/LWS (\%) & $3.27^{b}$ & $3.46^{\mathrm{a}}$ & $3.52^{\mathrm{a}}$ & $3.55^{\mathrm{a}}$ & 0.09 & 0.04 \\
\hline PRFW $(g)$ & $31.6^{\mathrm{b}}$ & $34.6^{a}$ & $35^{a}$ & $36.6^{\mathrm{a}}$ & 1.75 & 0.01 \\
\hline Ratio PRFW/LWS (\%) & $1,48^{\mathrm{b}}$ & $1,61^{\mathrm{a}}$ & $1,64^{\mathrm{a}}$ & $1,72^{\mathrm{a}}$ & 0,08 & 0.04 \\
\hline Ratio PRFW/CCW (\%) & $2.40^{\mathrm{b}}$ & $2.53^{a}$ & $2.47^{a}$ & $2.51^{\mathrm{a}}$ & 0.03 & 0.01 \\
\hline SW (g) & $273.3^{c}$ & $281^{b}$ & $296.6^{a}$ & $293.3^{a}$ & 4.26 & 0.04 \\
\hline Ratio SW/LWS (\%) & $12.8^{c}$ & $13.1^{\mathrm{b}}$ & $13.9^{a}$ & $13.8^{\mathrm{a}}$ & 0.59 & 0.04 \\
\hline WFDT $(\mathrm{g})$ & 333.3 & 330.6 & 335 & 330 & 9.88 & 0.48 \\
\hline Ratio WFDT/LWS (\%) & 15.6 & 15.4 & 15.7 & 15.5 & 0.43 & 0.57 \\
\hline FPW $(g)$ & $233.3^{b}$ & $233.3^{\mathrm{b}}$ & $284^{a}$ & $305^{\mathrm{a}}$ & 16.24 & 0.02 \\
\hline RPW (g) & $368.3^{b}$ & $385^{a}$ & $398^{a}$ & $408^{a}$ & 4.86 & 0.04 \\
\hline IPW (g) & 286 & 287 & 281 & 290 & 6.12 & 0.64 \\
\hline Ratio FPW/HCW (\%) & $16.91^{b}$ & $17.06^{\mathrm{b}}$ & $19.92^{a}$ & $19.82^{\mathrm{a}}$ & 0.29 & 0.01 \\
\hline Ratio RPW/HCW (\%) & 27.90 & 28.18 & 28.05 & 27.89 & 0.93 & 0.62 \\
\hline Ratio IPW/HCC (\%) & 21.66 & 20.98 & 19.78 & 19.84 & 0.93 & 0.90 \\
\hline \multicolumn{7}{|c|}{ Chemical composition of the meat } \\
\hline $\mathrm{pH}$ & $6.04^{\mathrm{b}}$ & $6.7^{\mathrm{a}}$ & $6.77^{a}$ & $6.72^{\mathrm{a}}$ & 0.04 & 0.01 \\
\hline Moisture content(\% of DM) & $65.43^{\mathrm{b}}$ & $67.43^{\mathrm{a}}$ & $67.28^{\mathrm{a}}$ & $66.79^{a}$ & 0.34 & 0.01 \\
\hline Protein (\% of DM) & $20.55^{b}$ & $21.85^{\mathrm{a}}$ & $22.07^{a}$ & $22.03^{\mathrm{a}}$ & 0.23 & 0.01 \\
\hline Fat $(\%$ of DM) & $7.7^{\mathrm{b}}$ & $8.7^{a}$ & $8.87^{a}$ & $8.89^{a}$ & 0.26 & 0.01 \\
\hline Ash (\% of DM) & $1.02^{\mathrm{b}}$ & $1.04^{\mathrm{a}}$ & $1.05^{\mathrm{a}}$ & $1.08^{\mathrm{a}}$ & 0.03 & 0.01 \\
\hline
\end{tabular}

In each line, the numbers followed by the same exponents do not differ significantly at $p<0.05$. LWS=Live weight at slaughter, $\mathrm{HCW}=$ Hot carcass weight, $\mathrm{CCW}=$ Cold carcass weight, $\mathrm{LW}=$ Liver weight, PRFW=Peri-renal fat weight, $\mathrm{SW}=\mathrm{Skin}$ weight, WFDT=Weight of full digestive tract, FPW=Front part weight, RPW=Rear part weight, IPW=Intermediate part "rable" weight

Table-7: Economic efficiency of replacing soybean meal with DAKM and alfalfa with DTP in fattening rabbits.

\begin{tabular}{lcccc}
\hline Parameters & $\mathbf{0 \%}$ & $\mathbf{3 0 \%}$ & $\mathbf{4 0 \%}$ & $\mathbf{6 0 \%}$ \\
\hline Live weight at 33 days (g) & 808 & 811 & 810 & 814 \\
Live weight at 77 days (g) & 1992 & 2095 & 2099 & 2073 \\
Total weight gain (kg) & 1.18 & 1.28 & 1.29 & 1.26 \\
Price (DZD/kg live weight) & 400 & 400 & 400 & 400 \\
Incomes in total weight gain DZD/kg & 473.60 & 513.60 & 515.60 & 503.60 \\
Total feed intake/rabbit (kg) & 4.03 & 4.13 & 32.39 & 3.91 \\
Price of one kg of feed, DZD & 38.43 & 33.91 & 129.11 & 29.35 \\
The total cost of rabbit feed, DZD/kg & 154.96 & 139.93 & 3.99 & 114.75 \\
Economic efficiency (\%) & 3.06 & 120.10 & 130.67 & 4.39 \\
Relative economic efficiency & 100 & 373.67 & 386.49 & 143.60 \\
Net income DZD/kg produced meat & 318.64 & 388.85 \\
\hline
\end{tabular}

DAKM $=$ Detoxified apricot kernel meal, DTP $=$ Dehydrated tomato pulp

of experimental formulations without any change in feed intake level during the whole rearing period; it was probably dependent on the increase in the sulfur amino acid content of the experimental batches. Indeed, several authors, such as Colin et al. [30], Colin [31], Berchiche et al. [32], and Taboada et al. [33], agree that diets rich in sulfur amino acids allow better growth performance.

However, the study of Ahmed et al. [34] on the incorporation rates of $10 \%, 20 \%$, and $30 \%$ DTP in the rabbit diet found no significant difference in growth performance compared to the control lot. The joint incorporation of DAKM and DTP resulted in an increase in crude cellulose and lignin, allowing the experimental batches a better valorization, as reported by Colin [31]; however, this remains dependent on the fiber source $[35,36]$ and the nature of the parietal compounds [37]. The ADGs (33-77 days) in the white population of the experimental plots were similar to those reported by Hannachi-Rabia et al. [38] (29.3 g/days) and Lounaouci-Ouyed et al. [39] (30.4 g/days), lower than those reported by Benali et al. [40] (34 g/days) and Mennani et al. [10] (32 g/days), and higher than those of [41] (27.49 g/days) and [42] (23.80 g/days).

The CI values during the whole rearing period were similar to the results of [43] (3.2-3.6) and are 
within the standards recommended for intensive European rearing (3.60-3.82) [44].

All slaughter parameters were improved in proportion to the incorporation rate of DAKM and DTP (from $30 \%$ to $60 \%)(p<0.05)$, except for the weight of the full digestive tract and saddle. However, for DAKM and DTP incorporation rates of $10-30 \%$, Mennani et al. [9], Mennani et al. [10] reported no differences in slaughter parameters and carcass characteristics between the batches. This suggests that these agro-industrial byproducts, especially DAKMs, incorporated in up to $60 \%$ in rabbit fattening diets, did not affect the digestive tract and saddle weights.

The nutritional value of rabbit meat is highly variable $[45,46]$, resulting in a highly variable chemical composition depending on the part of the carcass studied [47] and different production factors [48], especially the feed [49]. In this sense, the introduction of DAKMs and DTPs in rabbit fattening diets induced better meat composition performances in the experimental lots $(30 \%, 40 \%$, and $60 \%)$ compared to the control lot, while remaining similar between them. For lower levels of DAKM $(10 \%, 20 \%$, and $30 \%)$, Mennani et al. [9], Mennani et al. [10] observed an improving meat chemical composition; this remained different between the experimental lots, with a significant decrease in fat content which, on the other hand, significantly increased in our study. This was contrary to the increase in the fat content of experimental lots due to higher DAKM incorporation rates.

The price per kilogram of feed produced by the experimental $60 \%$ group created a financial gain of 40.21 DZD due to the low-cost price of agro-industrial byproducts and inflationary prices of soybean meal and alfalfa, which are entirely imported, depending on the fluctuations in world stock markets.

\section{Conclusion}

The DAKM/DTP complex can be considered a good source of protein $(58.41 \%)$ and fiber $(45.62 \%)$. This can be used as an alternative to the soybean cake/ alfalfa hay complex, with a substitution rate of up to $60 \%$, without any negative effects on growth rates, food conversion, and food consumption. It improved the live weights, all slaughter parameters, carcass characteristics, and meat chemical composition while reducing the cost of feed consumed. These encouraging results allow us to put forward the idea of increasing the substitution rates to determine the optimal incorporation rates.

\section{Authors' Contributions}

LO: Prepared the ground conditions and collected the data. YA: Performed the analysis of the data. AM: Carried out and drafted the economic analysis. FA: Designed the study and drafted it. RA: Revised the manuscript. All authors have read and approved the final manuscript.

\section{Acknowledgments}

We would like to thank the CMEP PHC TASSILI project for technical help. The authors did not receive any funds for this study.

\section{Competing Interests}

The authors declare that they have no competing interests.

\section{Publisher's Note}

Veterinary World remains neutral with regard to jurisdictional claims in published institutional affiliation.

\section{References}

1. El-Sabrout, K. and Aggag, S.A. (2015) Use of inter simple sequence repeats and protein markers in assessing genetic diversity and relationships among four rabbit genotypes. World Rabbit Sci., 23(4): 283-288.

2. Khalil, M.H., Shebl, M.K., Kosba, M.A., El-Sabrout, K. and Zaki, N. (2016) Estimate the contribution of incubation parameters influence egg hatchability using multiple linear regression analysis. Vet. World, 9(8): 806-810.

3. Guermah, H., Maertens, L. and Berchiche, M. (2016) Nutritive value of brewers' grain and maize silage for fattening rabbits. World Rabbit Sci., 24(3): 183-189.

4. Arbouche, R., Arbouche, F., Arbouche, H.S. and Arbouche, Y. (2012) Effects on growth performance of the incorporation of apricot kernel meal in the broiler ration. Rev. Méd. Vét., 163(10): 475-479.

5. Arbouche, R., Arbouche, F., Arbouche, H.S. and Arbouche, Y. (2014) Effects of the nature of nitrogen complement (apricot kernel cake vs. soybean meal) on fattening performance and carcass quality of lambs Ouled Djellal (Algeria). Rev. Méd. Vét., 165(11-12): 338-343.

6. Chapoutot, P., Rouillé, B. and Renauld, B. (2018) Co-products of the food industry: Quality food resources not to be neglected INRA. Prod. Anim., 31(3): 201-220.

7. Baa, A., Arbouche, F., Arbouche, R., Montaigne, E., Arbouche, Y. and Arbouche, H.S. (2019) Effects of incorporating oasis byproducts on fattening performance and carcass characteristics of Ouled Djellal lamb. Vet. World, 11(10): 1397-1403.

8. Bara, Y., Arbouche, R., Arbouche, Y., Montaigne, E., Baa, A. and Arbouche, F. (2019) Effects of replacing corn with cull dates and rumen content extract on production performances and the characteristics of broiler chicken carcasses. Rev. Ponte, 75(8): 137-148.

9. Mennani, A., Arbouche, R., Arbouche, Y., Montaigne, E., Arbouche, F. and Arbouche, H.S. (2017) Effects of incorporating agro-industrial byproducts into diet of New Zealand rabbits: Case of rebus of date and apricot kernel meal. Vet. World, 10(12): 1456-1463.

10. Mennani, A., Arbouche, Y., Arbouche, R., Montaigne, E., Arbouche, F. and Arbouche, H.S. (2019) Effects of incorporating cull dates and apricot kernel cake on fattening performances and carcass characteristics of local rabbits. Rev. Ponte, 75(9): 1-14.

11. Ouzzir, L., Arbouche, F. and Arbouche, Y. (2020) Detoxified apricot kernel meal in local rabbit fattening: Effects on growth performances and slaughter parameters. Rev. Ponte, 76(6): 1-10.

12. MADR (2016) Statistiques. Ministère de L'agriculture et du Développement Rural, Algérie [Statistics. Ministry of Agriculture and Rural Development (Algeria)].

13. Valérie, H. and Tran, G. (2016) Marc de tomate, tomato processing co-product. Adv. Food Res., 17(3): 77-135.

14. Peiretti, P.G., Gai, F., Rotolo, L., Brugiapaglia, A. and 
Gasco, L. (2013) Effects of tomato pomace supplementation on carcass characteristics and meat quality of fattening rabbits. Meat Sci., 95(2): 345-351.

15. Arbouche, F., Arbouche, R., Arbouche, Y., Arbouche, H.S. and Mennani, A. (2018) Tables of Composition and Nutritional Value of North African Raw Materials and Agro-industrial Byproducts for Ruminant feed. Université de Sétif, Algérie.

16. El-Adawy, T.A., Rahma, H., El-Badawey, A.A., Gomaa, M.A., Lásztity, R. and Sarkadi, L. (1994) Biochemical studies of some non-conventional sources of proteins. Part 7. Effect of detoxification treatments on the nutritional quality of apricot kernels. Nahrung, 38(1): 12-20.

17. Ferradji, A., Imerzouken, M., Malek, N. and Boudour, N. (2001) Effects of some parameters on the oil extraction of apricot kernels by pressing. Ann. Inst. Nat. Agro., 22: 49-59.

18. Cantier, J., Vezinhet, A., Rouvier, R., Dauzier, L., Bouthier, E., Bressot, C., Paolantonacci, S. and Scheller, M.C. (1969) Growth halometry in rabbits (Oryctolagus cuniculus). I. Main organs and tissues. Ann. Biol. Anim. Biochim. Biophys., 9(1): 5-39.

19. Ouhayoun, J. (1983) The growth and development of the fattening rabbit. Cuni. Sci., 7(1): 1-15.

20. Gabrial, G.N., El-Nahry, F.I., Awadalla, M.Z. and Girgis, S.M. (1981) Unconventional protein sources: Apricot seed kernels. Z. Ernahrungswiss. Suppl., 20(3): 208-215.

21. Association of Analytical Chemists. (1990) Official Method of Analysis. 15 $5^{\text {th }}$ ed. Association of Analytical Chemists, Arlington, Virginia.

22. Lebas, F. (2016) Estimation of Digestible Energy Content and Protein Digestibility of Raw Materials by the Rabbit with a System of Equations. Proceeding $11^{\text {th }}$ World Rabbit Congress, Qingdao, China. p293-298.

23. Waffda (2002) Food Formulation Software Version 1.4 for Feeding Rabbits. Available from: https://www.en.scribd.com/ doc/284432876/formulation-lapin. Retrieved on 1-03-2018.

24. Zotte, A.D., Princz, Z., Metzger, S., Szabó, A., Radnai, I., Biró-Németh, E., Orova, Z. and Szendro, Z. (2009) Response of fattening rabbits reared under different housing conditions. 2. Carcass and meat quality. Livest. Sci., 122(1): 39-47.

25. Asar, M.A., Osman, M., Yakout, H.M. and Safoat, A. (2010) Utilization of corn-cob meal and faba bean straw in growing rabbits diets and their effects on performance, digestibility and economical efficiency. Egypt. Poult. Sci., 30(2): 415-442.

26. Sonelgaz. (2019) National Electricity and Gas Company Algiers Algeria. Sonelgaz, Algeria.

27. AWD. (2019) Economic Statistics, Water Distribution Agency, Algiers, Algeria.

28. De Blas, J.C. (2013) Nutritional impact on health and performance in intensively reared rabbits. Animal, 7(1): 102-111

29. Kadi, S.A., Belaidi-Gater, N., Oudai, H., Bannelier, C., Berchiche, M. and Gidenne, T. (2012) Nutritive Value of Fresh Sulla (Hedysarum flexuosum) as a Sole Feed for Growing Rabbits. Proceeding $10^{\text {th }}$ World Rabbit Congress, Sharm El-Sheikh, Egypt. p507-511.

30. Colin, M., Arkhurst, G., Lebas, F., Cousin, M.C. and Sardi, G. (1973) Effects of methionine addition to the diet on growth performance in rabbits. Ann. Zootech., 22(4): 485491. Available from: https://www.hal.archives-ouvertes.fr/ hal-00887315/document. Retrieved on 01-04-2020.

31. Colin, M. (1978) Effects of methionine or cysteine supplementation of diets deficient in sulfur amino acids on rabbit growth performance. Ann. Zootech., 27(1): 9-16.

32. Berchiche, M., Lebas, F. and Ouhayoun, J. (1995) Utilisation of field beans by growing rabbits. 1-effects of supplementations aimed at improving the sulfur amino acid supply.
World Rabbit Sci., 3(1): 35-40.

33. Taboada, E., Mendez, J. and De Blas, J. (1996) The response of highly productive rabbits to dietary sulphur amino acid content for reproduction and growth. Reprod. Nutr. Dev., 36(2): 191-203.

34. Ahmed, S.S, El-Gendy, K.M, Ibrahim, H, Rashwan, A.A. and Tawfeek, M.I. (1994) Growth performance, digestibility, carcass traits and some physiological aspects of growing rabbits fed tomato pomace as a substitution for alfalfa meal. Egypt. J. Rabbit Sci., 4(1): 1-18.

35. Kadi, S.A., Mouhous, A., Djellal, F., Senhadji, Y., Tiguemit, N. and Gidenne, T. (2017) Fig-tree leaves and Sulla hay (Hedysarum flexuosum) in the diet of growing rabbits. Livest. Res. Rural Dev., 29(5): 86.

36. Harouz-Cherifi, Z., Kadi, S.A., Mouhous, A., Bannelier, C., Berchiche, M. and Gidenne, T. (2018) Effect of increasing level of brewers grains in diets of rabbits on carcass quality and economic efficiency. World Rabbit Sci., 26(1): 27-34.

37. Gidenne, T. (2003) Fibres in rabbit feeding for digestive troubles prevention: Respective role of low-digested and digestible fiber. Livest. Prod. Sci., 81(2-3): 105-117.

38. Hannachi-Rabia, R., Kadi, S.A., Bannelier, C., Berchiche, M. and Gidenne, T. (2017) The dry seeds of broad bean (Vicia faba major L) for fattening rabbits: Effect on growth and slaughter performance. Livest. Res. Rural Dev., 29(3): 50.

39. Lounaouci-Ouyed, G., Berchiche, M. and Gidenne, T. (2014) Effects of substitution of soybean meal-alfalfa-maize by a combination of field bean or pea with hard wheat bran on digestion and growth performance in rabbits in Algeria. World Rabbit Sci., 22(2): 137-146.

40. Benali, N., Ainbaziz, H., Dahmani, Y., Djellout, B., Belabbas, R., Tennah, S., Zenia, S., Cherrane, M. and Temim, S. (2018) Effects of the energy content of the feed on the performance and some biological parameters of growing rabbits. Livest. Res. Rural Dev., 30(3): 51.

41. Belabbas, R., García, M.L., Ainbaziz, H. and Benali, N. (2019) Growth performances, carcass traits, meat quality, and blood metabolic parameters in rabbits of local Algerian population and synthetic line. Vet. World, 12(1): 55-62.

42. Cherfaoui, A. (2015) Evaluation of the Production Performance of Rationally Reared Rabbits in Algeria, Thèse de Doctorat en Sciences Biologiques. Université Mouloud Mammeri de Tizi-Ouzou, Algérie.

43. Dehalle, C. (1981) Balance between nitrogen and energy in the diet of growing rabbits. Ann. Zootech., 30(2): 197-208.

44. Gidenne, T., Garreau, H., Drouilhet, L., Aubert, C. and Maertens, L. (2017) Improving feed efficiency in rabbit production, a review on nutritional, techno-economical, genetic and environmental aspects. Anim. Feed Sci. Technol., 225(2017): 109-122.

45. El-Medany, S.A. and El-Reffaei, W.H.M. (2015) Evaluation canola meal on growing rabbits; nutritionally and on their nutritional meat quality. J. Food Nutr. Res., 3(4): 220-234.

46. Haque, A., Rahman, M. and Bora, J. (2016) Effect of breed, weaning age and feeding regime on chemical composition of rabbit meat. Int. J. Vet. Sci. Anim. Husbandry, 1(1): 12-13.

47. Pla, M., Pascual, M. and Ariño, B. (2004) Protein, fat and moisture content of retail cuts of rabbit meat evaluated with the NIRS methodology. World Rabbit Sci., 12(3): 149-158.

48. Zotte, A.D. (2002) Perception of rabbit meat quality and major factors influencing the rabbit carcass and meat quality. Livest. Prod. Sci., 75(1): 11-32.

49. Abd-Allah, S.M.S. and Abd-Elaziz, D.M. (2018) Nutritional value and quality profile of fresh rabbit meat in Assiut city, Egypt. Int. J. Res. Agric. Food Sci., 4(7): 1-15. 